\title{
INVESTIGATION OF THE EFFECT OF VARIED SCHOOLBAG WEIGHT ON THE HEALTH OF PRIMARY STUDENTS: A QUANTITATIVE PLANTAR PRESSURE STUDY
}

\author{
STUDIUL INFLUENTEI GREUTĂTII VARIABILE A GHIOZDANULUI ASUPRA SĂNĂTĂTII ELEVILOR: O ANALIZĂ \\ CANTITATIVĂ A PRESIUNII PLANTARE
}

\author{
Nan ZHOU, Jin ZHOU, Luming YANG, Wuyong CHEN* \\ National Engineering Laboratory for Clean Technology of Leather Manufacture, Sichuan University, Chengdu, 610065, China, \\ wuyong.chen@163.com
}

\begin{abstract}
INVESTIGATION OF THE EFFECT OF VARIED SCHOOLBAG WEIGHT ON THE HEALTH OF PRIMARY STUDENTS: A QUANTITATIVE PLANTAR PRESSURE STUDY ABSTRACT. The aim of this study was to explore the effects of varied schoolbag weight on biomechanics of primary students in terms of planter pressure distribution, so as to clarify the threshold of the safety weight bearing for primary students. Sixty healthy children from primary school between the grade 1 to 6 were recruited and those with any scoliosis or foot injury were excluded. Changes of plantar pressure with weight bear increasing in terms of parameters of mean pressure (MP), contact area (CA), pressure-time integral (PTI) and Timecost were measured and the data were analyzed by model of ANOVA with significant level of 0.05 and confident interval of $95 \%$. Our results show that pressure of $0 \% \mathrm{BW}, 5 \% \mathrm{BW}$ and $10 \% \mathrm{BW}$ were significantly lower than those of $15 \% \mathrm{BW}$ and $20 \% \mathrm{BW}$ under the majority of foot regions, particularly at the medial forefoot and rearfoot. Thereby, our study suggested that the weight of primary students' bag should not exceed 15\% BW.
\end{abstract}

KEY WORDS: primary students, school bag, foot biomechanics, safety weight bearing

STUDIUL INFLUENTEI GREUTĂTII VARIABILE A GHIOZDANULUI ASUPRA SĂNĂTĂTII ELEVILOR: O ANALIZĂ CANTITATIVĂ A PRESIUNII PLANTARE REZUMAT. Scopul acestui studiu a fost de a explora influenţa ghiozdanelor de diferite greutăţi asupra biomecanicii piciorului la elevii din învăţământul primar, în ceea ce priveşte distribuţia presiunii plantare, astfel încât să se clarifice pragul de siguranţă al greutăţii pentru elevi. S-au recrutat şaizeci de elevi sănătoşi de clasele 1-6, iar cei cu scolioză sau leziuni la nivelul piciorului au fost excluşi. S-au măsurat modificările presiunii plantare odată cu creşterea greutăţii în ceea ce priveşte următorii parametri: presiunea medie (MP), zona de contact (CA), integrala presiune-timp (PTI) şi durata, iar datele au fost măsurate utilizând analiza de varianţă unifactorială (ANOVA) cu nivelul de semnificaţie de 0,05 şi intervalul de încredere de $95 \%$. Rezultatele noastre arată că presiunea pentru grupele de $0 \%$ greutate corporală (BW), $5 \%$ BW şi 10\% BW a fost semnificativ mai mică decât cea pentru grupele $15 \%$ BW şi 20\% BW în majoritatea regiunilor piciorului, în special în zona medie a antepiciorului şi la retropicior. Astfel, studiul nostru a sugerat că greutatea ghiozdanului elevilor din învăţământul primar nu ar trebui să depăşească $15 \%$ din greutatea corporală.

CUVINTE CHEIE: elevi de şcoală primară, ghiozdan, biomecanica piciorului, prag de siguranţă al greutăţii

ÉTUDE DE L'INFLUENCE DU POIDS VARIABLE DU CARTABLE SUR LA SANTÉ DES ÉTUDIANTS: UNE ANALYSE QUANTITATIVE DE LA PRESSION PLANTAIRE RÉSUMÉ. Le but de cette étude a été d'explorer l'influence des différents poids des cartables sur la biomécanique du pied aux élčves dans l'enseignement primaire, en termes de répartition de la pression plantaire afin de clarifier le seuil de poids de sécurité pour les étudiants. On a recruté soixante élčves en bonne santé de classes 1-6, et ceux avec des lésions du pied ou de la scoliose ont été exclus. On a mesuré les changements de la pression plantaire avec l'augmentation du poids par rapport aux paramčtres suivants: la pression moyenne (MP), la région de contact (CA), l'intégrale pression-temps (PTI) et la durée, et les données ont été mesurées en utilisant une analyse de variance (ANOVA) avec le seuil de signification de 0,05 et l'intervalle de confiance ŕ $95 \%$. Nos résultats montrent que la pression de groupes de $0 \%$ du poids corporel (BW), $5 \%$ BW et 10\% BW était significativement inférieure ŕ celui pour les groupes $15 \%$ BW et 20\% BW dans la plupart des régions du pied, en particulier dans la région moyenne de l'arričre-pied et l'avant-pied. Ainsi, notre étude suggčre que le poids du cartable pour les élčves de l'école primaire ne doit pas dépasser $15 \%$ du poids corporel.

MOTS-CLÉS: étudiants d'école primaire, cartable, biomécanique du pied, seuil de poids de sécurité

\section{INTRODUCTION}

Excessive weight of schoolbag and its effect on the children's development were of interest to researchers. The human body can bear a certain weight and the weight significantly affects the way

\section{INTRODUCERE}

Greutatea excesivă a ghiozdanului şi influenţa acesteia asupra dezvoltării copilului au prezentat interes pentru cercetători. Corpul uman poate suporta o anumită greutate, iar greutatea afectează în mod semnificativ încărcarea şi

* Correspondence to: Wuyong CHEN, National Engineering Laboratory for Clean Technology of Leather Manufacture, Sichuan University, Chengdu, 610065, China, email: wuyong.chen@163.com 
of loading and movement, such as obesity and body deformity. However, different from obesity, weight increasing caused by carrying bags, particularly for primary school students, is more harmful, since not only is the foot loading a higher plantar pressure, but also centre of body is modified, which could cause instability whilst walking, so as to hamper children's normal development. Thereby, schoolbag should be designed ergonomically and its influences on the child development should not be ignored.

Currently, studies were reported on the issue of the schoolbag and children's development. Studies have been conducted [1-3] on the physical reactions of children who walked with four varied school bag weights and their outcomes showed that the weight did not have a significant effect on gait, but a fifteen minute-walk with $20 \%$ body weight had a significant influence on children's body postures. Whereas, Troussier et al. [4] measured the biomechanics parameters of 1178 French students and they found that habitual or a long-term overweight might cause low back pain and musculoskeletal disorders. Similar findings could also be seen in the research of other experts [58]. Therefore, an American exercise physiologist [9] suggested that weight of schoolbag should be lower than $15 \%$ bodyweight and this criterion was widely adopted by most primary schools in the USA.

In terms of plantar pressure distribution, Meng Zhaoli et al. [10] studied the plantar pressure distribution of school-age children with different schoolbag weights, and their results implied that the peak pressure under $2^{\text {nd }}$ and $3^{\text {rd }}$ metatarsals increased with $4 \mathrm{~kg}$ bag weight bearing whilst normal walking and the center of pressure vibrated a lot in the mediallateral direction; besides, they also narrated that possibility of varus or valgus deformity was high as the schoolbag weight was increasing. Although previous studies have indicated the effects of different weight bearing on walking posture, a systematic and quantitative study on primary students was rarely reported. mişcarea, ducând la obezitate şi la deformarea corpului. Cu toate acestea, în mod diferit de obezitate, greutatea crescută cauzată de purtarea ghiozdanului, în special pentru elevii de şcoală primară, a fost mai dăunătoare, deoarece pe lângă faptul că piciorul suportă o presiune plantară mai mare, centrul degreutate al corpului s-a modificat, ceea cear putea provoca instabilitate în timpul mersului, în aşa măsură încât să împiedice dezvoltarea normală a copilului. Prin urmare, ghiozdanul trebuie proiectat ergonomic, iar influenţele acestuia asupra dezvoltării copilului nu trebuie ignorate.

În prezent, s-au raportat studii cu privire la problemele legate de ghiozdan şi dezvoltarea copiilor. Sau efectuat studii [1-3] privind reacţiile fizice ale copiilor care au mers pe jos purtând în spate patru ghiozdane cu greutăţi variate, iar rezultatele au arătat că greutatea nu a avut un efect semnificativ asupra mersului, însă cincisprezece minute de mers pe jos cu un surplus de greutate de $20 \%$ a avut o influenţă semnificativă asupra posturii corpului. Troussier şi colab. [4] au măsurat parametrii biomecanici ai unui grup de 1178 de studenţi francezi şi au descoperit că purtarea obişnuită sau pe termen lung a unui exces de greutate ar putea duce la dureri în regiunea lombară şi tulburări musculoscheletice. Rezultate similare au fost obţinute şi de alţi specialişti [5-8]. Prin urmare, un fiziolog american [9] a sugerat că greutatea ghiozdanului trebuie să reprezinte mai puţin de $15 \%$ din greutatea corporală şi acest criteriu au fost adoptat pe scară largă de majoritatea şcolilor primare din SUA.

În ceea ce priveşte distribuţia presiunii plantare, Meng Zhaoli şi colab. [10] au studiat distribuţia presiunii plantare la şcolari cu ghiozdane de diferite greutăţi, iar rezultatele lor au sugerat că presiunea maximă la al doilea şi al treilea metatarsian a crescut la purtarea unor ghiozdane de $4 \mathrm{~kg}$ în timpul mersului pe jos normal, iar centrul de presiune a vibrat mult în direcţia medial-lateral; în plus, au relatat, de asemenea, că posibilitatea de apariţie a deformărilor în varus sau valgus a crescut odată cu greutatea ghiozdanului. Deşi studii anterioare au indicat influenţele diferitelor greutăţi asupra posturii în timpul mersului, un studiu sistematic şi cantitativ asupra elevilor a fost foarte rar raportat. 
Hence, the aim of this study was to explore the effects of varied schoolbag weight on biomechanics of primary students in terms of plantar pressure distribution, so as to clarify the threshold of the safety weight bearing for primary students.

\section{METHODS}

\section{Participants}

Sixty elementary students between grade 1 and 6 (aged between 6 and 11) were recruited from a primary school in Sichuan Province. Subjects were excluded if they had any scoliosis or foot injury. The children's parents were aware of procedures and notes of experiment prior to test and their formal approval was given. This study was approved by the University's ethics committee and all the procedures of this study were confirmed with the principles of Helsinki declaration.

\section{Measurement}

Footscan force plate system (Rsscan, Belgium, 100 $\times 42 \times 12 \mathrm{~mm}$ ) was used for data collection. Five minutes warm up were provided before the measurement. Subjects were guided to walk through the force plate using the two steps protocol with a selfselected walk speed. Five groups of weight bearing were available: 0\% body weight (BW) (the control condition), 5\% BW, 10\% BW, 15\% BW and 20\% BW and each group was randomly arranged by researchers. Three measurements were required and one minute rest was set between each measurement.

\section{Data Processing}

Footscan 7 gait $2^{\text {nd }}$ generation (V7.97, Rsscan, Belgium) was used for statistical analysis. Foot plantar was divided into ten regions: hallux (T1), lesser toes (T2-5), $1^{\text {st }}$ metatarsal (MTH1), $2^{\text {nd }}$ metatarsal $(\mathrm{MTH} 2), 3^{\text {rd }}$ metatarsal $(\mathrm{MTH} 3), 4^{\text {th }}$ metatarsal (MTH4), $5^{\text {th }}$ metatarsal (MTH5), midfoot (MF), medial heel (MH) and lateral heel (LH) and under each region, plantar pressure parameters
Prin urmare, scopul acestui studiu a fost de a explora influenţa ghiozdanelor de diferite greutăţi asupra biomecanicii elevilor din învăţământul primar, în ceea ce priveşte distribuţia presiunii plantare, astfel încât să se clarifice pragul de siguranţă al greutăţii pentru elevi.

\section{METODE}

\section{Participanţi}

Şaizeci de elevi din clasele 1-6 (cu vârstele cuprinse între 6 şi 11 ani) au fost recrutaţi de la o şcoală primară din provincia Sichuan. Subiecţii au fost excluşi dacă au avut scolioză sau leziuni la picior. Părinţii copiilor li s-au adus la cunoştinţă procedurile şi condiţiile experimentului înainte de testare şi aceştia şiau dat apoi acordul oficial. Acest studiu a fost aprobat de către comitetul de etică al universităţii şi toate procedurile acestui studiu au respectat principiile declaraţiei de la Helsinki.

\section{Măsurători}

Pentru colectarea datelor s-a utilizat placa de forţă Footscan (Rsscan, Belgia, $100 \times 42 \times 12 \mathrm{~mm}$ ). S-au alocat cinci minute pentru încălzire înainte de măsurători. Subiecţii au fost îndrumaţi să meargă pe placa de forţă utilizând protocolul în două etape, cu o viteză de mers la alegere. S-au constituit cinci grupe de greutate: $0 \%$ greutate corporală (BW) (grupa martor), $5 \%$ BW, 10\% BW, 15\% şi 20\% BW şi fiecare grupă a fost aranjată în mod aleatoriu de către cercetători. Au fost necesare trei măsurători şi s-a alocat un minut de odihnă între măsurători.

\section{Prelucrarea datelor}

S-a utilizat programul Footscan 7 pentru sisteme de a 2-a generaţie (V7.97, Rsscan, Belgia) pentru analiza statistică. Zona plantară a fost împărţită în zece regiuni: haluce (T1), degetele mai mici (T2-5), primul metatarsian (MTH1), al doilea metatarsian (MTH2), al treilea metatarsian (MTH3), al patrulea metatarsian (MTH4), al cincilea metatarsian (MTH5), piciorul median (MF), partea mediană a călcâiului $(\mathrm{MH})$ şi partea laterală a 
such as mean pressure (MP), contact area (CA), pressure time integral (PTI) and time cost were calculated.

\section{Statistical Analysis}

The mean of three trials of each subject was calculated first, and then result of 1-sample K-S test shows that all the data confirmed the normal distribution. The independent t-test was used to compare the variables between left foot and right foot. Since there were significant differences between left foot and right foot, only the data of left foot was selected for analysis. The effect of different weight on plantar pressure was analyzed by one-way ANOVA with significance level of $\alpha=0.05$ and confidence interval was $95 \%$.

\section{RESULTS}

The gender ratio of subjects was 1:1, the mean height was $1.35 \pm 0.10 \mathrm{~m}$, and the mean body weight was $29.9 \pm 7.0 \mathrm{~kg}$. The basic information about subjects was shown in Table 1. călcâiului (LH) şi în fiecare regiune s-au calculat parametri precum presiunea medie (MP), zona de contact (CA), integrala presiune-timp (PTI) şi durata.

\section{Analiza statistică}

Mai întâi s-a calculat media a trei încercări pentru fiecare subiect, apoi rezultatul testului K-S cu o singură probă arată că toate datele respectă distribuţia normală. Testul t independent a fost utilizat pentru a compara variabilele dintre piciorul stâng şi piciorul drept. Deoarece au existat diferenţe semnificative între piciorul stâng şi piciorul drept, doar datele obţinute de la piciorul stâng au fost selectate pentru analiză. Influenţa diferitelor greutăţi asupra presiunii plantare a fost analizată prin analiza de varianţă unifactorială cu nivelul de semnificaţie $\alpha=0,05$ şi intervalul de încredere de $95 \%$.

\section{REZULTATE}

Raportul de gen al subiecţilor a fost de 1:1, înălţimea medie a fost $1,35 \pm 0,10 \mathrm{~m}$, iar greutatea medie a fost de $29,9 \pm 7.0 \mathrm{~kg}$. Informaţiile de bază ale subiecţilor sunt prezentate în Tabelul 1.

Table 1: General characteristics of participants

Tabelul 1: Caracteristicile generale ale participanţilor

\begin{tabular}{|c|c|c|c|c|c|c}
\hline $\begin{array}{c}\text { Grade } \\
\text { Clasa }\end{array}$ & 1 & 2 & 3 & 4 & 5 & 6 \\
\hline $\begin{array}{c}\text { Age (years) } \\
\text { Vârsta (ani) }\end{array}$ & $7.1 \pm 0.3$ & $7.9 \pm 0.3$ & $8.9 \pm 0.3$ & $9.5 \pm 0.5$ & $10.6 \pm 0.5$ & $11.5 \pm 0.7$ \\
\hline $\begin{array}{c}\text { Height }(\mathrm{m}) \\
\text { Inălţime }(\mathrm{m})\end{array}$ & $1.25 \pm 0.06$ & $1.28 \pm 0.04$ & $1.31 \pm 0.04$ & $1.33 \pm 0.07$ & $1.46 \pm 0.09$ & $1.48 \pm 0.07$ \\
\hline $\begin{array}{c}\text { Weight }(\mathrm{kg}) \\
\text { Greutate }(\mathrm{kg})\end{array}$ & $25.5 \pm 5.2$ & $24.7 \pm 2.6$ & $25.7 \pm 1.4$ & $25.9 \pm 3.8$ & $36.7 \pm 8.2$ & $40.8 \pm 7.2$ \\
\hline $\begin{array}{c}\text { BMI } \\
\text { IMC }\end{array}$ & $15.9 \pm 1.81$ & $14.9 \pm 0.9$ & $14.9 \pm 0.5$ & $14.4 \pm 0.94$ & $16.8 \pm 1.9$ & $18.5 \pm 3.05$ \\
\hline
\end{tabular}

The effect of age and weight were evaluated independently by the one-way ANOVA, and only the weight was approved to be important in the change of plantar pressure, where significant variations were observed within each weight bearing for the
Influenţa vârstei şi greutăţii au fost evaluate în mod independent prin ANOVA unifactorială şi s-a confirmat că doar greutatea este importantă la modificarea presiunii plantare, observându-se variaţii semnificative la purtarea diferitelor greutăţi pentru 
parameters of $\mathrm{MP}(\mathrm{P}=0.002<0.05)$, $\mathrm{PTI}(\mathrm{P}=0.001<$ $0.05)$ and Timecost $(P=0.006<0.05)$.

As the weight of bag increased, plantar pressure increased in all ten regions, particularly MP $(P=0.034<$ $0.05)$ and $\mathrm{PTI}(\mathrm{P}=0.007<0.05)$ at $\mathrm{HM}$; besides, Timecost at MTH1 $(P=0.049<0.05)$ and MP at MTH3 $(P$ $=0.039<0.05)$ and MTH4 $(P=0.006<0.05)$ were demonstrated to be significantly affected by the weight increasing.

Comparing within weight groups, at the HM area, MP of $0 \%$ BW was significantly lower than that of $15 \%$ BW $(P=0.03<0.05)$ and $20 \%$ BW $(P=0.002<0.05)$; meanwhile, $\mathrm{PTI}$ of $0 \% \mathrm{BW}$ and $5 \% \mathrm{BW}$ at this region was apparently smaller than those of $15 \% \mathrm{BW}(\mathrm{P}=0.006$ for $0 \% B W, p=0.005$ for $5 \% B W)$ and $20 \% B W(P=0.011$ for $0 \% B W, P=0.01$ for $5 \%$ BW), respectively. Similarly, in terms of MP at MTH3 and MTH4, $0 \%$ BW and $5 \%$ BW at this region was apparently lower than those of $15 \% \mathrm{BW}$ ( $P=0.04$ for $0 \%$ BW of MTH3, $p=0.004$ for $0 \%$ BW of MTH4, $\mathrm{P}=0.037$ for $5 \%$ BW of MTH3, $p=0.017$ for $5 \%$ BW of MTH4) and 20\% BW ( $P=0.017$ for $0 \%$ BW of MTH3, $p=0.005$ for $0 \%$ BW of MTH4, $P=0.015$ for $5 \%$ BW of MTH3, $p=0.018$ for $5 \%$ BW of MTH4) individually. parametrii $M P(P=0,002<0,05)$, ITP $(p=0,001<0,05)$ şi durata $(p=0,006<0,05)$.

$\mathrm{Pe}$ măsură ce creşte greutatea ghiozdanului, presiunea plantară creşte în toate cele zece regiuni, în special MP $(p=0,034<0,05)$ şi PTI $(P=0,007<0,05)$ la $\mathrm{MH}$; în plus, durata la MTH1 $(\mathrm{P}=0,049<0,05)$ şi MP la MTH3 ( $P=0,039<0,05)$ şi MTH4 $(P=0,006<0,05)$ s-au dovedit a fi afectate în mod semnificativ de greutatea în creştere.

Comparând grupele de greutate, în regiunea HM, MP la $0 \%$ BW a fost semnificativ mai mică decât cea de la 15\% BW ( $p=0,03<0,05)$ şi 20\% BW ( $p=0,002<0,05)$; între timp, PTI la 0\% BW şi 5\% BW în această regiune a fost aparent mai mică decât la $15 \%$ BW $(P=0,006$ pentru $0 \% B W, p=0,005$ pentru $5 \% B W$ ), respectiv la $20 \% \mathrm{BW}(\mathrm{P}=0,011$ pentru $0 \% \mathrm{BW}, \mathrm{P}=0,01$ pentru $5 \%$ $B W)$. În mod similar, în ceea ce priveşte MP în regiunile MTH3 şi MTH4, la 0\% BW şi 5\% BW a fost aparent mai mică decât la $15 \%$ BW ( $\mathrm{P}=0,04$ pentru $0 \%$ BW la MTH3, $p=0,004$ pentru $0 \%$ BW la MTH4, $P=0,037$ pentru $5 \%$ BW la MTH3, $p=0,017$ pentru 5\% BW la MTH4) şi 20\% BW ( $\mathrm{P}=0,017$ pentru $0 \%$ BW la MTH3, $\mathrm{p}=0,005$ pentru $0 \%$ BW la MTH4, $\mathrm{P}=0,015$ pentru 5\% BW la MTH3, $p=$ 0,0185\% BW la MTH4).
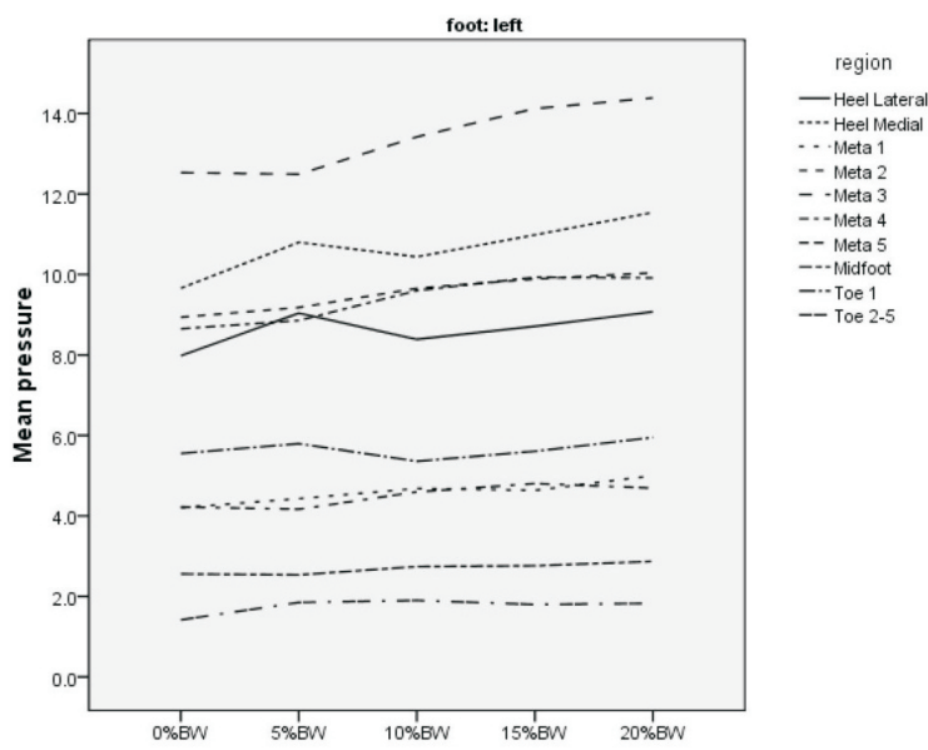

Figure 1. The variation of mean pressure in different school bags' weight for each region $\left(\mathrm{N} / \mathrm{cm}^{2}\right)$

Figura 1. Variaţia presiunii medii la utilizarea ghiozdanelor cu diferite greutăţi pentru fiecare regiune $\left(\mathrm{N} / \mathrm{cm}^{2}\right)$ 
Table 2: The mean pressure values in different school bags' weight for each region $\left(\mathrm{N} / \mathrm{cm}^{2}\right)$ Tabelul 2: Valorile presiunii medii la utilizarea ghiozdanelor cu diferite greutăţi pentru fiecare regiune $\left(\mathrm{N} / \mathrm{cm}^{2}\right)$

\begin{tabular}{|c|c|c|c|c|c|}
$\begin{array}{c}\text { Region } \\
\text { Regiune }\end{array}$ & $0 \% \mathrm{BW}$ & $5 \% \mathrm{BW}$ & $10 \% \mathrm{BW}$ & $15 \% \mathrm{BW}$ & $20 \% \mathrm{BW}$ \\
\hline $\mathrm{T} 1$ & $5.6 \pm 2.2$ & $5.8 \pm 2.6$ & $5.4 \pm 2.4$ & $5.6 \pm 2.3$ & $5.9 \pm 2.3$ \\
\hline T2-5 & $1.4 \pm 0.9$ & $1.8 \pm 1.4$ & $1.9 \pm 1.7$ & $1.8 \pm 1.7$ & $1.7 \pm 1.2$ \\
\hline MTH1 & $4.2 \pm 2.1$ & $4.4 \pm 2.1$ & $4.7 \pm 2.0$ & $4.6 \pm 2.0$ & $5.0 \pm 2.1$ \\
\hline MTH2 & $8.9 \pm 2.7$ & $9.2 \pm 2.5$ & $9.7 \pm 2.7$ & $9.9 \pm 2.9$ & $10.0 \pm 2.9$ \\
\hline MTH3 & $12.5 \pm 3.8$ & $12.5 \pm 4.2$ & $13.4 \pm 4.5$ & $14.1 \pm 4.3$ & $14.4 \pm 4.3$ \\
\hline MTH4 & $8.7 \pm 2.3$ & $8.9 \pm 2.4$ & $9.6 \pm 2.4$ & $9.9 \pm 2.6$ & $9.9 \pm 2.5$ \\
\hline MTH5 & $4.2 \pm 1.6$ & $4.2 \pm 1.7$ & $4.6 \pm 1.8$ & $4.8 \pm 1.9$ & $4.7 \pm 2.1$ \\
\hline MF & $2.6 \pm 0.8$ & $2.5 \pm 0.8$ & $2.7 \pm 0.8$ & $2.8 \pm 0.8$ & $2.9 \pm 0.8$ \\
\hline MH & $9.7 \pm 2.2$ & $10.1 \pm 2.2$ & $10.4 \pm 2.2$ & $11.0 \pm 2.4$ & $11.5 \pm 2.4$ \\
\hline LH & $8.0 \pm 1.6$ & $8.3 \pm 1.9$ & $8.4 \pm 1.8$ & $8.7 \pm 2.0$ & $9.1 \pm 2.1$ \\
\hline
\end{tabular}

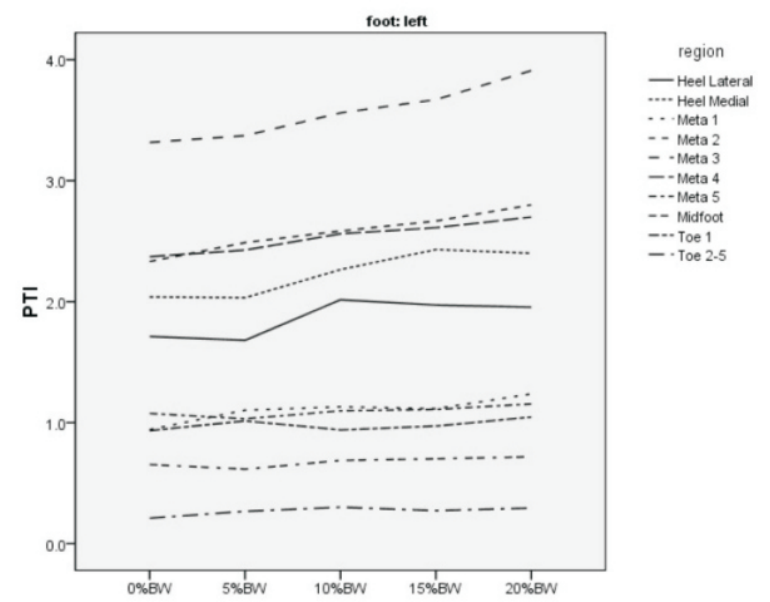

Figure 2. The variation of relative PTI in different school bags' weight for each region (\%)

Figura 2. Variaţia PTI relative la utilizarea ghiozdanelor cu diferite greutăţi pentru fiecare regiune (\%)

Table 3: The relative PTI values in different school bags' weight for each region (\%) Tabelul 3: Valorile PTI relative la utilizarea ghiozdanelor cu diferite greutăţi pentru fiecare regiune (\%)

\begin{tabular}{c|c|c|c|c|c|}
$\begin{array}{c}\text { Region } \\
\text { Regiune }\end{array}$ & $0 \% \mathrm{BW}$ & $5 \% \mathrm{BW}$ & $10 \% \mathrm{BW}$ & $15 \% \mathrm{BW}$ & $20 \% \mathrm{BW}$ \\
\hline \hline T1 & $0.9 \pm 0.4$ & $1.0 \pm 0.5$ & $0.9 \pm 0.5$ & $1.0 \pm 0.5$ & $1.0 \pm 0.4$ \\
\hline T2-5 & $0.2 \pm 0.2$ & $0.3 \pm 0.2$ & $0.3 \pm 0.3$ & $0.3 \pm 0.3$ & $0.3 \pm 0.3$ \\
\hline MTH1 & $0.9 \pm 0.5$ & $1.1 \pm 0.6$ & $1.1 \pm 0.6$ & $1.1 \pm 0.5$ & $1.2 \pm 0.6$ \\
\hline MTH2 & $2.3 \pm 0.9$ & $2.5 \pm 0.9$ & $2.6 \pm 1.0$ & $2.7 \pm 1.0$ & $2.8 \pm 1.0$ \\
\hline MTH3 & $3.3 \pm 1.2$ & $3.4 \pm 1.3$ & $3.6 \pm 1.4$ & $3.7 \pm 1.3$ & $3.9 \pm 1.4$ \\
\hline MTH4 & $2.4 \pm 0.8$ & $2.4 \pm 0.8$ & $2.6 \pm 0.8$ & $2.6 \pm 0.9$ & $2.7 \pm 0.9$ \\
\hline MTH5 & $1.1 \pm 0.5$ & $1.0 \pm 0.5$ & $1.1 \pm 0.5$ & $1.1 \pm 0.5$ & $1.2 \pm 0.6$ \\
\hline MF & $0.7 \pm 0.3$ & $0.6 \pm 0.3$ & $0.7 \pm 0.3$ & $0.7 \pm 0.3$ & $0.7 \pm 0.3$ \\
\hline MH & $2.0 \pm 0.7$ & $2.0 \pm 0.8$ & $2.3 \pm 0.7$ & $2.4 \pm 0.9$ & $2.4 \pm 0.8$ \\
\hline LH & $1.7 \pm 0.6$ & $1.7 \pm 0.7$ & $2.0 \pm 1.6$ & $2.0 \pm 0.7$ & $2.0 \pm 0.6$ \\
\hline
\end{tabular}




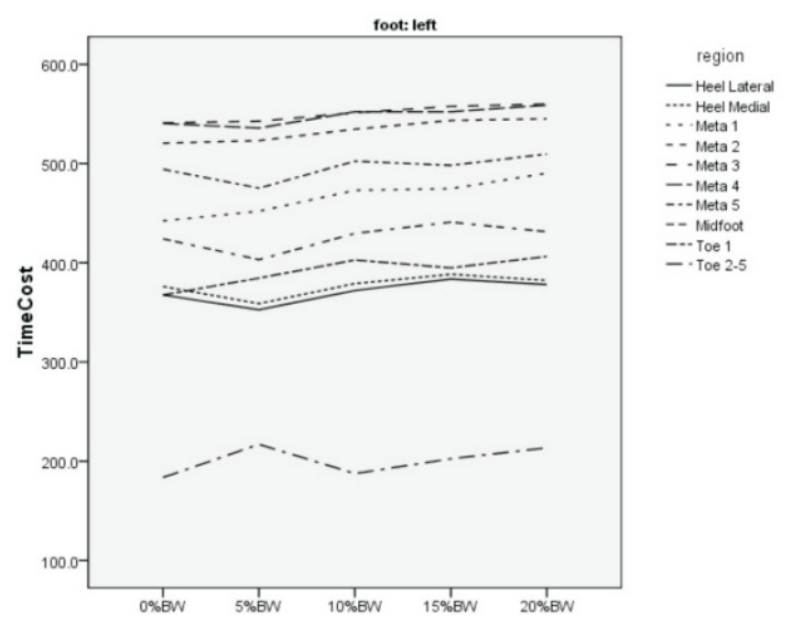

Figure 3. The variation of timecost in different school bags' weight for each region (\%)

Figura 3. Variaţia duratei la utilizarea ghiozdanelor cu diferite greutăţi pentru fiecare regiune (\%)

Table 4: The timecost values in different school bags' weight for each region (\%)

Tabelul 4: Valorile duratei la utilizarea ghiozdanelor cu diferite greutăţi pentru fiecare regiune (\%)

\begin{tabular}{|c|c|c|c|c|c|}
\hline $\begin{array}{c}\text { Region } \\
\text { Regiune }\end{array}$ & $0 \% \mathrm{BW}$ & $5 \% \mathrm{BW}$ & $10 \% \mathrm{BW}$ & $15 \% \mathrm{BW}$ & $20 \% \mathrm{BW}$ \\
\hline \hline T1 & $367.5 \pm 104.3$ & $384.6 \pm 92.2$ & $402.8 \pm 105.6$ & $394.9 \pm 106.7$ & $406.4 \pm 101.0$ \\
\hline T2-5 & $183.5 \pm 125.0$ & $217.0 \pm 125.3$ & $187.5 \pm 127.7$ & $202.4 \pm 132.4$ & $213.5 \pm 107.3$ \\
\hline MTH1 & $442.3 \pm 106.8$ & $452.0 \pm 84.0$ & $473.1 \pm 95.4$ & $474.7 \pm 102.0$ & $490.3 \pm 87.8$ \\
\hline MTH2 & $520.5 \pm 81.6$ & $523.2 \pm 73.5$ & $534.7 \pm 79.1$ & $543.5 \pm 82.2$ & $545.2 \pm 70.7$ \\
\hline MTH3 & $540.9 \pm 72.0$ & $542.7 \pm 69.7$ & $551.3 \pm 75.7$ & $557.8 \pm 75.4$ & $560.0 \pm 68.0$ \\
\hline MTH4 & $540.4 \pm 72.7$ & $535.9 \pm 71.1$ & $552.3 \pm 71.3$ & $552.3 \pm 81.3$ & $559.0 \pm 70.9$ \\
\hline MTH5 & $494.3 \pm 95.4$ & $475.3 \pm 110.3$ & $502.5 \pm 87.7$ & $498.2 \pm 94.0$ & $509.6 \pm 91.6$ \\
\hline MF & $424.1 \pm 86.6$ & $403.2 \pm 86.7$ & $429.6 \pm 82.2$ & $441.0 \pm 91.9$ & $431.3 \pm 85.3$ \\
\hline MH & $376.1 \pm 83.9$ & $358.9 \pm 86.0$ & $379.0 \pm 83.5$ & $388.5 \pm 92.3$ & $382.3 \pm 84.5$ \\
\hline LH & $367.6 \pm 82.2$ & $352.6 \pm 84.8$ & $372.1 \pm 84.4$ & $383.6 \pm 91.7$ & $378.0 \pm 84.6$ \\
\hline
\end{tabular}

\section{DISCUSSION}

This study measured 60 healthy primary students' plantar pressure distribution with varied weight bearing and then systematically explored the relationship between the weight bearing and plantar pressure in terms of parameters of MP, CA, PTI and Timecost; finally a safety weight bearing threshold was proposed. Our outcomes show that when the

\section{DISCUTII}

Acest studiu a măsurat distribuţia presiunii plantare la 60 de elevi sănătoşi la purtarea unor greutăţi diferite şi apoi s-a explorat sistematic relaţia dintre greutate şi presiunea plantară prin intermediul parametrilor MP, CA, PTI şi durata, iar în cele din urmă a fost propus un prag de siguranţă al greutăţii. Rezultatele noastre arată că, atunci când greutatea a 
weight exceeded 15\% BW, MP, PTI and Timecost increased dramatically. Thereby, our study suggested that the weight of primary students' bag should not exceed $15 \%$ BW.

According to the tendency of plantar pressure with the weight bearing increasing, pressure at forefoot and rear foot rose fast, particularly at the MTH3 and MH. This finding implied that if child carries the bag for a long time, the heavy school bag might influence the child's forefoot and medial heel most, which could cause the collapse of transverse arch and make the foot in a posture of eversion. Additionally, from the result of $C A$, where the CA increased at arch, it suggested that eversion happened in order to keep balance whilst waling.

Studies [10-15] also reported that a larger plantar pressure loaded on forefoot could cause an increased possibility of varus or valgus deformity when children walked carrying schoolbag. Whereas, Meng Zhaoli et al. [10] studied the plantar pressure distribution of school-aged children with different schoolbag weights, and their results implied that the peak pressure under 2nd and 3rd metatarsals increased with $4 \mathrm{~kg}$ bags weight bearing whilst normal walking and the center of pressure vibrated a lot in the medial-lateral direction; besides, they also suggested that possibility of varus or valgus deformity was high as the schoolbag weight increased. The results of our study were consistent with the above ones.

In our study, an important finding of a threshold value of safety weight bearing for primary students was obtained and our ANOVA analysis significantly showed that pressure of the $0 \% \mathrm{BW}, 5 \% \mathrm{BW}$ and $10 \% \mathrm{BW}$ was significantly lower than those of $15 \%$ BW and $20 \%$ BW. In addition, in the group of younger students, 5\% BW weight bearing made the pressure shift from the rear foot to the forefoot, but the same change happened for elder students at $15 \% \mathrm{BW}$. This result also implied that a heavy bag was more harmful to the younger students.

Although positive results were found in our study, limitations such as walking velocity still existed and should be read with caution, since the velocity was selected by the children themselves and it might affect the way of gait and foot loading. Further, influence of depăşit 15\% BW, MP, PTI şi durata au crescut dramatic. Astfel, studiul nostru a sugerat că greutatea ghiozdanelor elevilor din învăţământul primar nu ar trebui să depăşească $15 \%$ din greutatea corporală.

Conform tendinţei presiunii plantare de a creşte odată cu greutatea, presiunea în zonele antepiciorului şi retropiciorului a crescut rapid, în special la MTH3 şi MH. Această constatare a sugerat că, dacă elevul poartă ghiozdanul un timp îndelungat, greutatea acestuia ar putea influenţa cel mai mult zona antepiciorului şi partea mediană a călcâiului, ceea ce ar putea provoca lăsarea boltei transversale şi eversia piciorului. În plus, pornind de la rezultatul obţinut pentru CA, creşterea CA în zona bolţii a sugerat că eversia a avut loc pentru a menţine echilibrul în timpul mersului.

Unele studii [10-15] au raportat, de asemenea, că o presiune plantară mai mare la nivelul antepiciorului ar putea mări şansele de apariţie a deformărilor de tip varus sau valgus atunci când copiii merg cu ghiozdanul în spate. Meng Zhaoli şi colab. [10] au studiat distribuţia presiunii plantare la copii de vârstă şcolară cu ghiozdane de diferite greutăţi, iar rezultatele lor au sugerat că presiunea maximă la al 2-lea şi al 3-lea metatarsian a crescut la purtarea unui ghiozdan cu greutatea de $4 \mathrm{~kg}$, în timpul mersului normal, iar centrul de presiune a vibrat mult în direcţia medial-laterală; în plus, aceştia au sugerat că posibilitatea apariţiei deformărilor de tip varus sau valgus a crescut odată cu creşterea greutăţii ghiozdanului. Rezultatele studiului nostruau fostîn concordanţă cu cele de mai sus.

Prin intermediul studiului nostru, am obţinut valoarea limită de greutate a ghiozdanului pentru elevii de şcoală primară, iar analiza ANOVA a arătat că presiunea pentru 0\% BW, 5\% BW şi 10\% BW a fost redusă în mod semnificativ faţă de cea pentru $15 \%$ BW şi $20 \%$ BW. În plus, în grupa elevilor mai mici, greutatea de $5 \%$ BW a deplasat presiunea de la retropicior la antepicior, aceeaşi schimbare având loc la elevii mai mari la greutatea de 15\% BW. Acest rezultat a sugerat, de asemenea, că ghiozdanul cu greutate mai mare este dăunător elevilor mai mici.

Deşi s-au obţinut rezultate pozitive, încă există limitări, cum ar fi viteza mersului, şi trebuie luate în considerare cu atenţie, deoarece viteza a fost aleasă de către copil şi ar putea afecta, la rândul ei, mersul şi încărcarea picioarelor. Mai mult, trebuie discutate în 
weight bearing on the gait cycle, the center of pressure trajectory, the angle between foot and the axes should be further discussed.

\section{CONCLUSION}

Overall, our study summarized that $15 \%$ BW was a threshold of a safety weight bearing for children and school bag's weight of primary students should be limited to less than $15 \%$ BW.

\section{Acknowledgments}

This study was funded by Guangzhou Huadu Science and Technology Plan Projects (2012, HD12CXY-G0016). We thank Sichuan University with study design and coordination of data collection. continuare influenţa greutăţii asupra ciclului mersului, traiectoria centrului de presiune, unghiul dintre picior şiaxe.

\section{CONCLUZII}

Per ansamblu, în urma studiului nostru, am ajuns la concluzia că pragul de greutate de 15\% BW reprezintă unul sigur pentru copii, iar greutatea ghiozdanului elevilor ar trebui să se limiteze la mai puţin de 15\% BW.

\section{Mulţumiri}

Acest studiu a fost finanţat de Autoritatea privind Proiectele Ştiinţifice şi Tehnologice Guangzhou Huadu (2012, HD12CXY-G0016). Mulţumim Universităţii Sichuan pentru designul de studiu şi coordonarea colectării datelor.

\section{REFERENCES}

1. Hong, Y., Cheung, C.K., Gait and posture responses to backpack load during level walking in children, Gait and Posture, 2003, 17, 28-33.

2. Foiasi, T., Pantazi, M., Children's Footwear - Health, Comfort, Fashion, Revista de Pielarie Incaltaminte (Leather and Footwear Journal), 2010, 10, 4, 45-60.

3. Malcoci, M., Darii, D., Influence Study of Satchels' Weight on Children's Health, Revista de Pielarie Incaltaminte (Leather and Footwear Journal), 2008, 8, 3, 53-60.

4. Troussier, B., Davoine, P., Gaudemaris, R.D. et al., Back pain in school children a study among 1178 pupils, Scand J Rehabil Med, 1994, 26, 3, 143-146.

5. Johnson, R.F., Knapik, J.J., Symptoms during load carrying effects of mass and load distribution during a $20 \mathrm{~km}$ road march, Percept Motor Skills, 1995, 81, 1, 331-338.

6. Zhou, J., Li, T., Xu, B., Chen, W., Investigation of Children's Plantar Pressure Distribution with Varied Angle of Hallux, Revista de Pielarie Incaltaminte (Leather and Footwear Journal), 2015, 15, 1, 3-14.

7. Zhou, J., Song, Y., Xu, B., Chen, W., Features of Plantar Pressure Distribution of Chinese Children Aged between Two and Eleven, Revista de Pielarie Incaltaminte (Leather and Footwear Journal), 2014, 14, 3, 135-146.

8. Zhou, J., Zhang, Y., Chen, W., Xu, B., Investigation of Children's Foot Arch Based on the Variation Between Static and Dynamic Footprint, Revista de Pielarie Incaltaminte (Leather and Footwear Journal), 2014, 14, 4, 205-216.

9. Forjuoha, S.N., Schuchmannb, J.A., Lane, B.L., Correlates of heavy backpack use by elementary school children, Public Health, 2004, 118, 7, 532-535.

10. Meng, Z., Yuan, W., Distribution of Planter Pressure in School Children during Walking with Different Loads on Their Backs, J Biomed Eng, 2008, 25, 4, 852-855.

11. Chen, H., Liu, H., Zhang, J. et al., Study on Plantar Pressure Distribution of People Walking with Different Backpack Load, J Biomed Eng, 2013, 30, 3, 525-529.

12. Zhou, L., Jiang, W., Liu, Q., Effect of different load on planter Pressure in Children during walking, Hebei Medicine, 
2014, 20, 7, 1173-1176.

13. An, D.H., Yoon, J.Y., Yoo, W.G. et al., Comparisons of the gait parameters of young Korean women carrying a singlestrap bag, Nurs Health Sci, 2010, 12, 87-93.

14. Garciaguirre, J.S., Adolph, K.E., Shrout, P.E., Baby Carriage: Infants Walking With Loads, Child Dev, 2007, 78, 2, 664680.

15. Gelalis, I.D., Ristanis, S., Nikolopoulos, A. et al., Load rate patterns in scoliotic children during gait: the impact of the schoolbag carriage and the importance of its position, Eur Spine J, 2012, 21, 1936-1941.

Article received/Data primirii articolului: 22.05.2015

Accepted/Acceptat la data: 21.08.2015 